Meta

Journal des traducteurs

Translators' Journal

\title{
Foreword / Avant-propos
}

\section{Susan Sammons}

Volume 38, numéro 1, mars 1993

La traduction et l'interprétation dans le nord du Canada

Translation and Interpretation in Northen Canada

URI : https://id.erudit.org/iderudit/004021ar

DOI : https://doi.org/10.7202/004021ar

Aller au sommaire du numéro

Éditeur(s)

Les Presses de l'Université de Montréal

ISSN

0026-0452 (imprimé)

1492-1421 (numérique)

Découvrir la revue

Citer ce document

Sammons, S. (1993). Foreword / Avant-propos. Meta, 38(1), 6-8.

https://doi.org/10.7202/004021ar

Ce document est protégé par la loi sur le droit d'auteur. L’utilisation des services d'Érudit (y compris la reproduction) est assujettie à sa politique d'utilisation que vous pouvez consulter en ligne.

https://apropos.erudit.org/fr/usagers/politique-dutilisation/
Cet article est diffusé et préservé par Érudit.

Érudit est un consortium interuniversitaire sans but lucratif composé de l’Université de Montréal, l'Université Laval et l'Université du Québec à Montréal. Il a pour mission la promotion et la valorisation de la recherche. https://www.erudit.org/fr/ 


\section{AVANT-PROPOS}

L'objectif de ce numéro spécial de Meta est de donner aux lecteurs un aperçu de quelques-uns des intérêts et des problèmes courants dans le domaine de l'interprétation et de la traduction des langues aborigènes dans les Territoires du Nord-Ouest. Les collaborateurs proviennent de plusieurs milieux et de diverses origines langagières.

La première section de ce numéro fait référence à la moitié est du territoire, où la langue aborigène est l'inuktitut. Les sujets abordés dans ces textes peuvent être divisés en quatre grandes catégories: l'analyse structurelle, les origines historiques, les problèmes courants de traduction et d'interprétation et la technologie informatique.

La seconde section de ce numéro se rapporte à la moitié ouest du territoire où différentes langues aborigènes sont parlées, avec prédominance déné. Les sujets abordés dans ces articles incluent l'analyse linguistique, l'entraînement des traducteurs et des interprètes, les problèmes courants de traduction et d'interprétation et l'alphabétisation en langage déné. Les niveaux d'alphabétisation dans l'Ouest sont de beaucoup inférieurs à ceux de l'Est et une large part du travail actuel dans l'Ouest se rapporte au domaine de la lecture et de l'écriture.

Il est à espérer que les lecteurs comprendront mieux les problèmes particuliers auxquels sont confrontés les traducteurs et les interprètes aborigènes du Nord canadien. Problèmes qui sont sensiblement différents de ceux rencontrés par leurs confrères du «Sud». De même, il est souhaité que les lecteurs comprendront mieux les différents problèmes et les enjeux en cause dans les parties est et ouest du territoire. En dépit de ces différences, les lecteurs remarqueront également les nombreuses similarités rencontrées partout dans le domaine de l'interprétation et de la traduction.

SusAn SAMMONS

Arctic College, Iqaluit, Canada

\section{FOREWORD}

The purpose of this special issue of Meta is to give a glimpse of some current problems and interests in the field of interpreting and translation in aboriginal languages in the Northwest Territories. Its contributors come from many fields and many language backgrounds.

The first section of this issue relates to the Eastern half of the territory where the aboriginal language is Inuktitut. The subjects dealt with in these papers may be divided into four broad categories: structural analysis, historical background, current problems in translation and interpretation and computer technology.

The second section of this issue relates to the Western half of the territory where several aboriginal languages are spoken, predominantly Dene. The subjects dealt with in these papers include linguistic analysis, interpreter/translator training, current problems in translation and interpretation and literacy in the Dene languages. Literacy levels in the West are much lower in the East, and a lot of work in the West is related to the fields of reading and writing in the Dene languages.

It is hoped that readers will gain some insights into the special problems faced by aboriginal interpreters and translators in Northern Canada which vary somewhat from problems faced by their southern counterparts. Similarly, it is hoped that readers will come to a greater understanding of the different problems and issues faced in the Eastern and Western parts of the territory. In spite of these differences, readers will also note the many similarities in interpreting and translating found everywhere. 


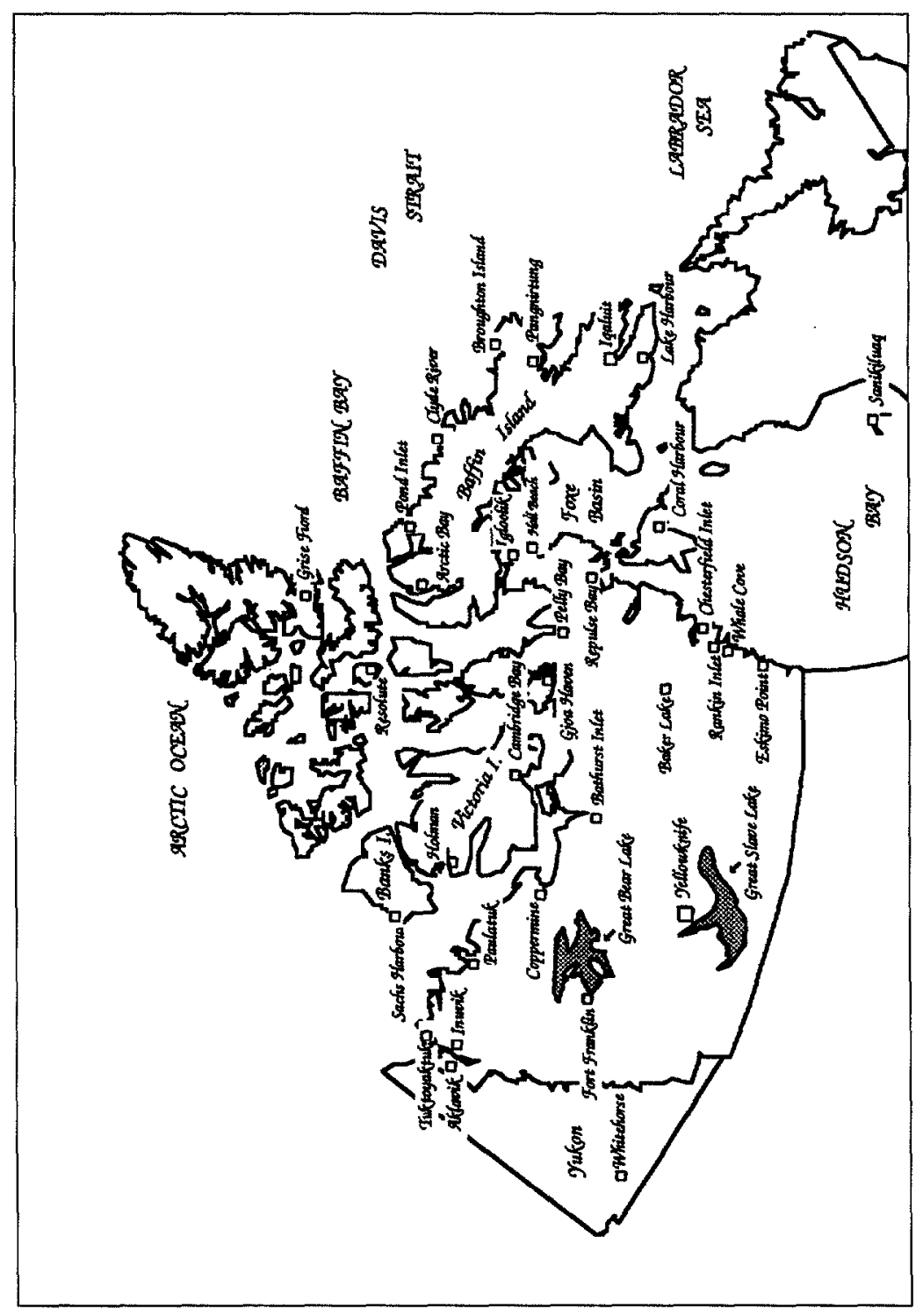




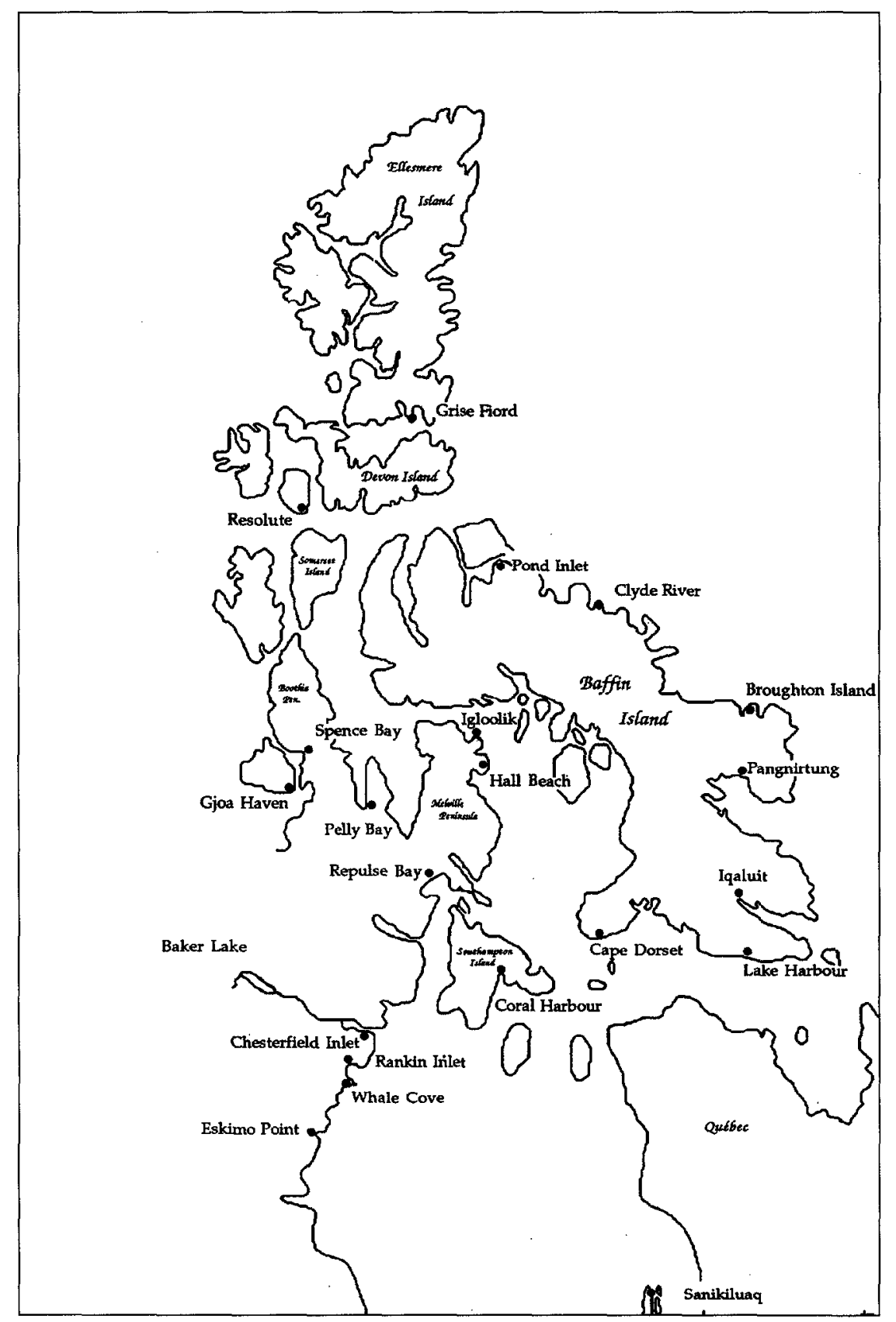

